\title{
Virus-like particles in a summer bloom of Emiliania huxleyi in the North Sea
}

\author{
Corina P. D. Brussaard ${ }^{1, *}$, Rob S. Kempers ${ }^{1}$, Arjen J. Kop ${ }^{1}$, Roel Riegman ${ }^{1}$, \\ Mikal Heldal $^{2}$ \\ ${ }^{1}$ Department of Biological Oceanography, Netherlands Institute for Sea Research, PO Box 59, 1790 AB Den Burg, Texel, \\ The Netherlands \\ ${ }^{2}$ Department of Microbiology and Plant Physiology, University of Bergen, Jahnebakken 5, N-5020 Bergen, Norway
}

\begin{abstract}
The importance of viruses in controlling a bloom of the coccolithophorid Emiliania huxleyi in the North Sea was investigated during summer 1993. Viral infection of $E$. huxleyi was highest in the decaying phase of the bloom. Up to $50 \%$ of E. huxleyi cells were visibly infected. For E. huxleyi, 2 types of virus-like particles are reported. They differed in size and were occassionally found within the same cell. The infection level of the large virus-like particles was never higher than $25 \%$. Viral lysis of E. huxleyi within the nitrogen-limited decaying phase of the bloom seemed an important source of organic carbon utilized by bacteria. In addition to infection in $E$. huxleyi, we also found severe viral infection in Chrysochromulina sp. Our results show that in natural ecosystems viruses can be a significant source of phytoplankton mortality, influencing phytoplankton (bloom) dynamics and the microbial food web
\end{abstract}

KEY WORDS: Emiliania huxleyi bloom - Viruses Viral lysis Bacterial production

\section{INTRODUCTION}

The existence of virus-like particles has been reported for many eukaryotic phytoplankton species (Dodds 1979, Van Etten et al. 1991). However, only a few reports are known on the potential importance of viruses as agents of mortality for phytoplankton. Mayer (1977) was one of the first reporting established viral infection of the Prasinophyte Micromonas pusilla. Transfer of an aliquot of infected culture to an uninfected unialgal culture of $M$. pusilla resulted in complete lysis. Cottrell \& Suttle (1991) showed that viruses which lysed $M$. pusilla were highly species-specific and geographically widespread. Suttle et al. (1991) documented 6 phytoplankton isolates of diverse taxonomy (including diatoms) that were susceptible to readily isolated viruses present in seawater. Furthermore, Suttle \& Chan (1995) isolated a virus which caused

-E-mail: cpdb@nioz.nl lysis when added to exponentially growing cultures of the Prymnesiophyte Chrysochromulina brevifilum.

Studies on the role of viruses as control mechanisms on the phytoplankton population level are even more scarce (Sieburth et al. 1988, Bratbak et al. 1993, Nagasaki et al. 1994). Bratbak et al. (1993) studied viral importance during a bloom of Emiliania huxleyi in mesocosms enriched with nitrate and phosphate. In some cases, viral lysis could account for 25 to $100 \%$ of the net mortality of $E$. huxleyi. These results indicate that viruses have the potential to play an important role in phytoplankton dynamics. Viral cell lysis results in the release of the cellular components (e.g. proteins, nucleic acids) in addition to viruses themselves, which will influence the nutrient and energy cycling in the microbial food web (Fuhrman 1992, Bratbak et al. 1994). Fuhrman (1992) showed that inclusion of viruses in a food web model led to decreased availability of hosts to higher trophic levels, and to increased respiration rates.

The aim of this study was to clarify the importance of viruses as mortality agents of the coccolithophorid 
Emiliania huxleyi, blooming under natural conditions in the North Sea during summer 1993. We report on viral infertion within the cells of E. huxleyi using electron microscopy and relate viral lysis to bacterial production. E. huxleyi has a world-wide distribution, may form extensive blooms and is a major producer of calcite (Balch et al. 1991), which makes it an important alga for studies on global biogeochemical cycles. Information on the viral mortality of E. huxleyi blooms is essential for a better understanding and modelling of carbon flows.

\section{MATERIAL AND METHODS}

Sampling site and chemical analyses. All samples were collected during a cruise aboard the RV 'Pelagia', from 28 June until 13 July 1993. Station locations are shown in Fig. 1. High levels of reflectance from the waters off the coast of Shetland, as observed by satellite images (Van der Wal et al. 1995), indicated large numbers of loose coccoliths during a bloom of Emiliania huxleyi. Based on level of reflectance we divided the stations into 3 regions: (A) region within the high reflectance area (Stns 4, 7, 15, $19 \mathrm{~S}$ and 30); (B) borderline zone (Stns 12,19N, 28 and 32); and (C) region

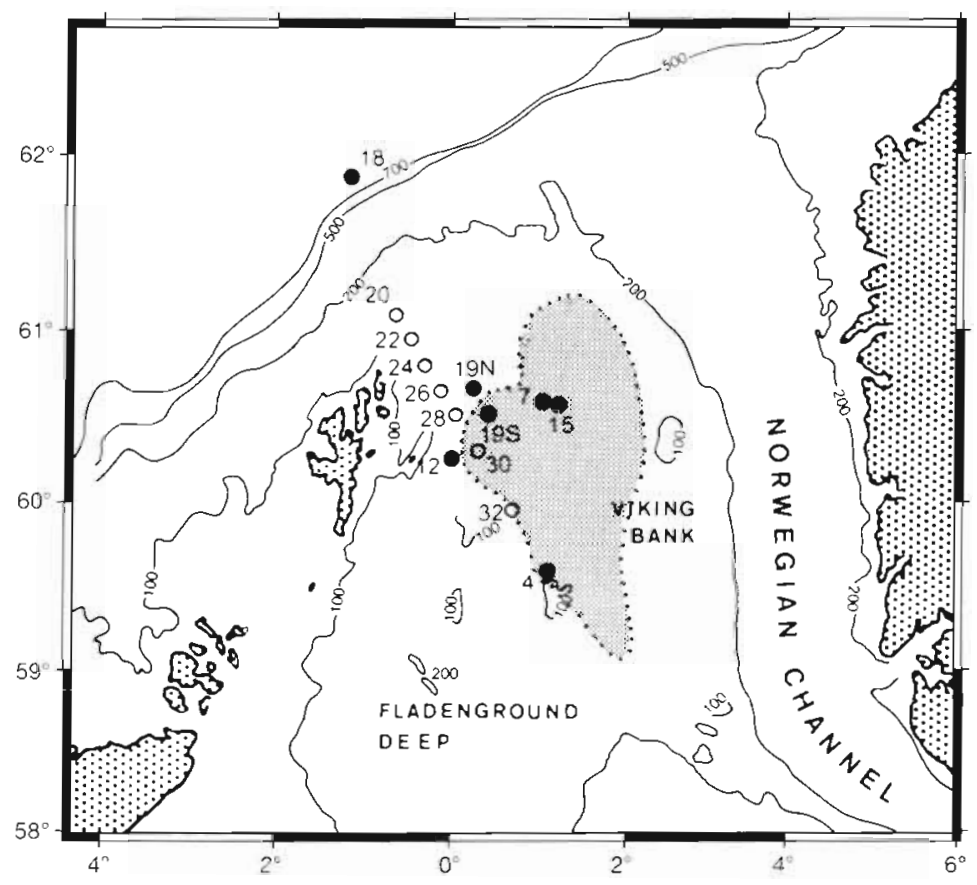

Fig. 1 Map of study area, showing the position of the stations investigated during a cruise off the coast of Shetland (North Sea) in June/July 1993. The high reflectance area (decaying phase of the Emilianı huxley) bloom studied), as observed by satellite images, is shaded. Location of main stations (Stns $4,7,12,15,18,19 \mathrm{~N}, 19 \mathrm{~S})(0)$; location of transect Stns $20-32$ outside the reflectance area (Stns 18 and 20-26). Vertical profiles of salinity and temperature were recorded for all stations with a Sea-Bird Electronic conductivity, temperature, depth profiles (CTD) (type SBE9+). Seawater samples were collected with a rosette sampler using 10.5 I NOEX bottles (Technicap, Cap d'Ail, France). Dissolved nutrients (ortho-phosphate, reactive silicate, ammonium-nitrogen, nitrate-nitrogen and nitrite-nitrogen) were measured in $0.2 \mu \mathrm{m}$ Acrodisc filtered water samples on a TRAAC 800 autoanalyzer (Technicon, Buffalo Grove, IL, USA).

Phytoplankton abundance and bacterial production. The number of Emiliania huxleyi coccospheres (living and dead) were obtained from Van der Wal et al. (1995, pers. comm.). Chlorophyll a (chl a) concentration was determined fluorimetrically according to Holm-Hansen et al. (1965). Samples for chl a were gently filtered through Whatman $G F / F$ filters and extracted in $90 \%$ acetone after homogenization. For several main stations (Stns 7, 12, 15, 19S) we divided algal biomass (obained from flow-cytometer countings of algal size classes in the upper $25 \mathrm{~m}$ of the water column; M. J. W Veldhuis pers. comm.) by the corresponding chl a concentration. The estimated average phytoplankton C:chl a ratio of $30 \pm 4$ was used throughout this study. Our estimated ratio equalled the C:chl a ratio for $E$. huxleyi, which was derived from the literature assuming $0.2 \mathrm{pg}$ chl a cell ${ }^{-1}$ as reported by Paasche \& Klaveness (1970) and Kristiansen (1987) and 6 pg $\mathrm{C}_{\text {cell }}{ }^{-1}$ as reported by Conte et al. (1995)

Bacterial production was determined with ${ }^{3} \mathrm{H}$-leucine incorporation into bacterial biomass according to Simon \& Azam (1989).

Virus-like particles. At 6 stations (Stns 7 . $12,15,18,19 \mathrm{~N}, 19 \mathrm{~S}$ ) we took samples of 10 to $130 \mathrm{l}$ at 15 to $25 \mathrm{~m}$ depth (chlorophyll maximum if present) for thin sectioning of cells. Samples were preserved with $2 \%$ formaldehyde and stored until use at $4^{\circ} \mathrm{C}$. After centrifugation (first step at $12000 \times g$ with a continuous centrifugation (LWA 205), and second step $10 \mathrm{~min}$ at $4000 \mathrm{rpm}(2600 \times g)$ with a Sigma (St. Louis, MO, USA) 2M centrifuge), the concentrated cells were washed in cacodylate buffer (0.1 M, pH = 7.4) for $30 \mathrm{~min}$ and postfixed with $2 \% \mathrm{OsO}_{4}$ in cacodylate buffer (Fluka, Switzerland) for $2 \mathrm{~h}$ at $4^{\circ} \mathrm{C}$. After dehydration in an alcohol series, cells were embedded in Epon (Fluka, Switzerland) for 24 h at $60^{\circ} \mathrm{C}$ using BEEM capsules (Biorad, Richmond, CA, USA) and sectioned on a Reichert OM U3 ultamicrotome. Thin sections were poststained with uranyl acetate $(3.5 \% ; 5 \mathrm{~min})$ followed by Reynolds 
Pb-citrate ( $5 \mathrm{~min})$, and viewed at $60 \mathrm{kV}$ using a Philips CM 10 transmission electron microscope. The number of cell sections examined for intracellular virus-like particles (VLPs) ranged between 100 and 250 in each sample. Special care was taken so as to count a sectioned cell only once. Particles were identified as viruses on the basis of size, staining properties and shape.

Free large VLPs (>120 nm) were counted in samples preserved with $1 \%$ glutaraldehyde (final conc.) according to Bratbak et al. (1990). Unfortunately, due to technical failure of the refrigerator used for storage, most samples were unsuitable for further use. We have only counts for transect Stns 20 to 32 .

\section{RESULTS}

\section{Hydrographical and chemical conditions}

Our study area is influenced by the inflow of ocean water from the North Atlantic between Scotland and Norway, and the outflow of North Sea water along the Scandinavian coast (Lee 1970). The latter has a lower salinity as a result of mixing with fresh water run-off from the land and low salinity water entering the North Sea from the Baltic. Stratification is well known to occur in this area and can be due to heating of the surface water during spring and summer or to a strong inflow of low-saline water. A low salinity layer ( 34 to $35 \mathrm{ppt}$, top $20 \mathrm{~m}$ ) at $\operatorname{Stns} 4,7$ and 15 indicated such an inflow of low-saline water and subsequent stratification. The impact of Atlantic water was clearly recorded for Stn 18 , with constant temperature and salinity of $10.6^{\circ} \mathrm{C}$ and $35.3 \mathrm{ppt}$, respectively, over the entire water column. All other stations showed a thermal stratification. Temperature in the mixed layer (depth 30 to $40 \mathrm{~m}$ ) ranged from 10.4 to $11^{\circ} \mathrm{C}$. Salinity was between 35.2 and 35.3 ppt over the entire water colunm. The $\mathrm{pH}$ ranged between 7.9 and 8.1 at all stations.

All nutrient depth profiles show enhanced concentrations below the thermocline. Concentrations of silicate ranged between 0.3 and $2 \mu \mathrm{M}$ in the mixed layer. Highest concentrations of phosphate, nitrate and nitrite in the mixed layer (Fig. 2) were measured in the region outside the high reflectance area. For phosphate and nitrate minimum values of 0.06 and $0.07 \mu \mathrm{M}$ were recorded, respectively. Nitrite concentrations ranged between 0 and $0.15 \mu \mathrm{M}$. Concentrations of ammonium in the mixed layer were usually between 0.3 and $1.6 \mu \mathrm{M}$.
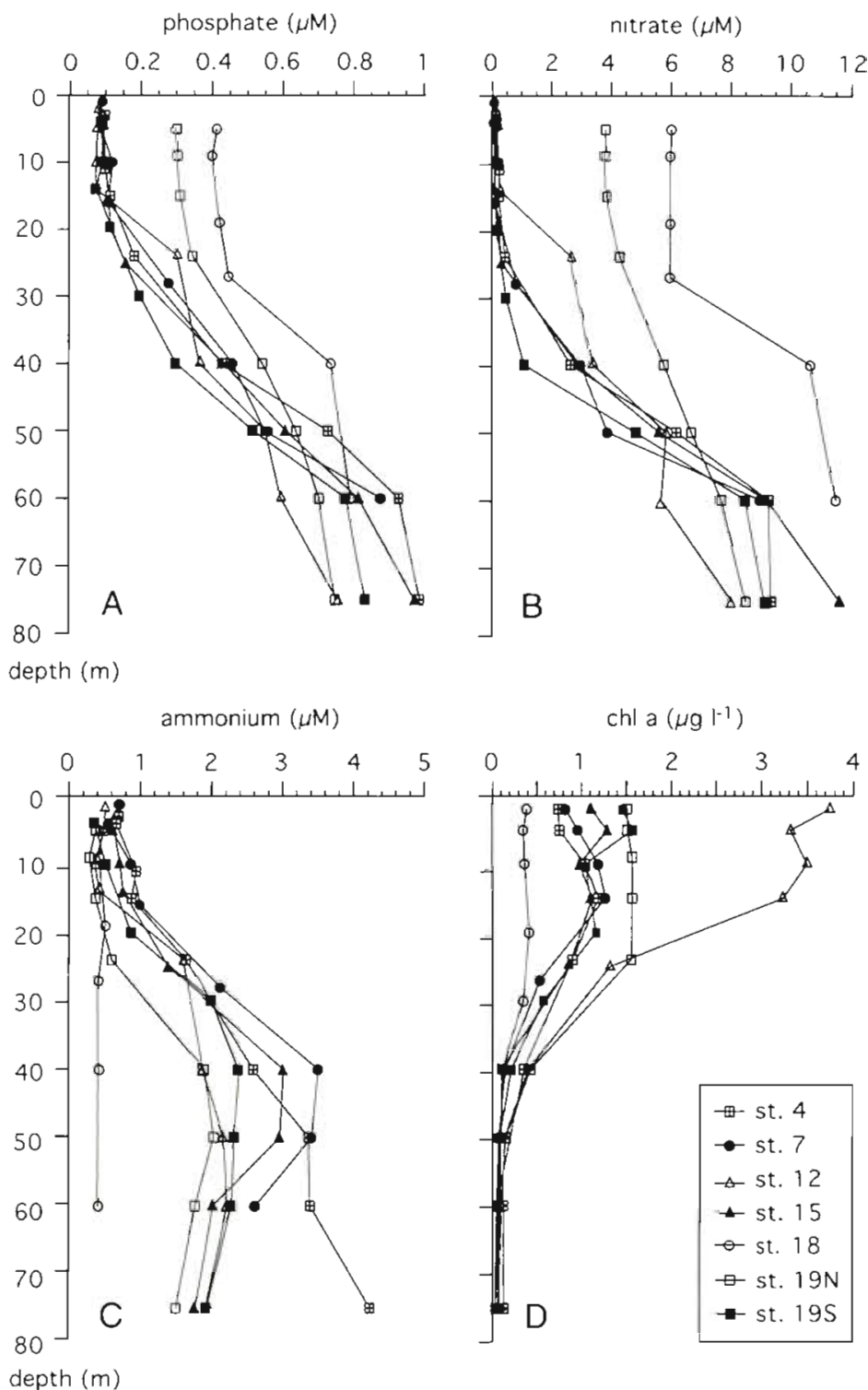

Fig. 2. Depth profiles of concentrations $(\mu \mathrm{M})$ of (A) phosphate, (B) nitrate, (C) ammonium, and (D) concentration $\left(\mu \mathrm{g}^{-1}\right.$ ) of chlorophyll a at the main stations during June/July 1993

\section{Phytoplankton occurrence and bacterial production}

For most stations chl a concentration in the mixed layer varied between 0.75 and $2.3 \mu \mathrm{g}^{-1}$ (Fig. 2; main stations). Exceptions were Stn 12, with values up to

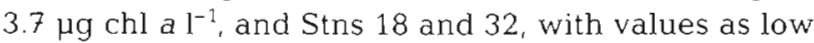

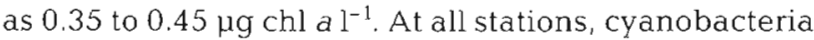
(Synechococcus sp.) were an important contributor of the algal community in terms of numbers. The North Atlantic station (Stn 18) was further characterised by high numbers of pico-eukaryotes, whereas diatoms were usually found in the borderline zone. Highest numbers of Emiliania huxleyi coccospheres (max. $1.8 \times$ $10^{6} \mathrm{l}^{-1}$ ) were found within the high reflectance area. 


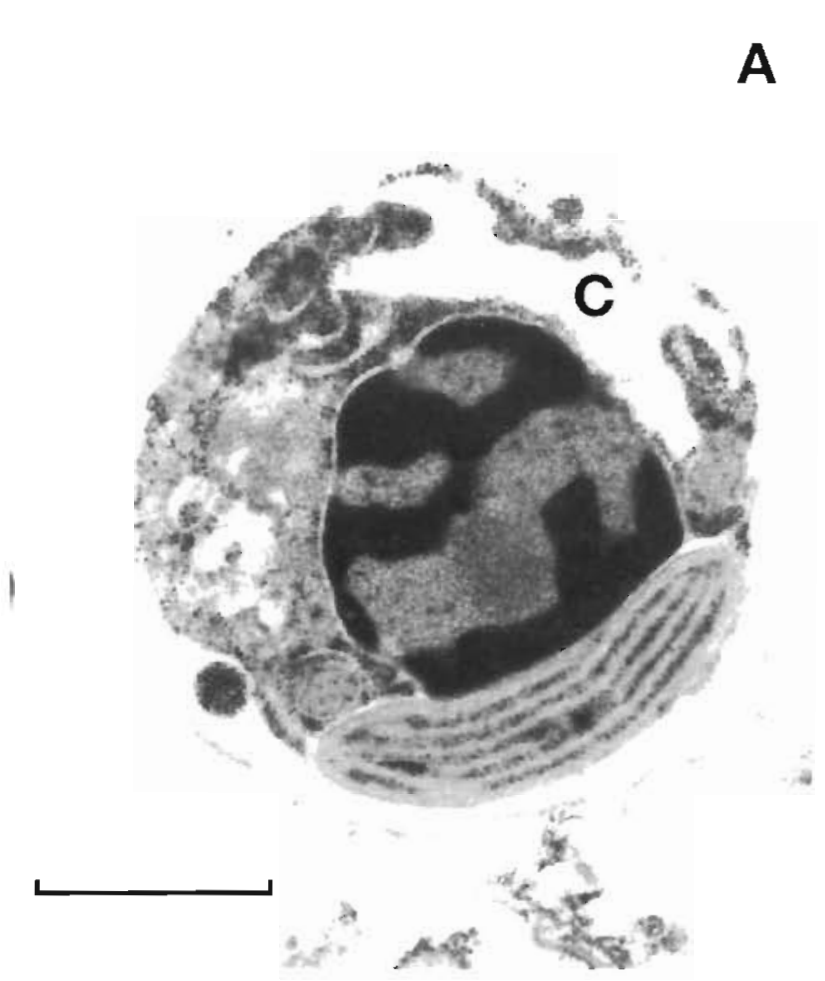

B

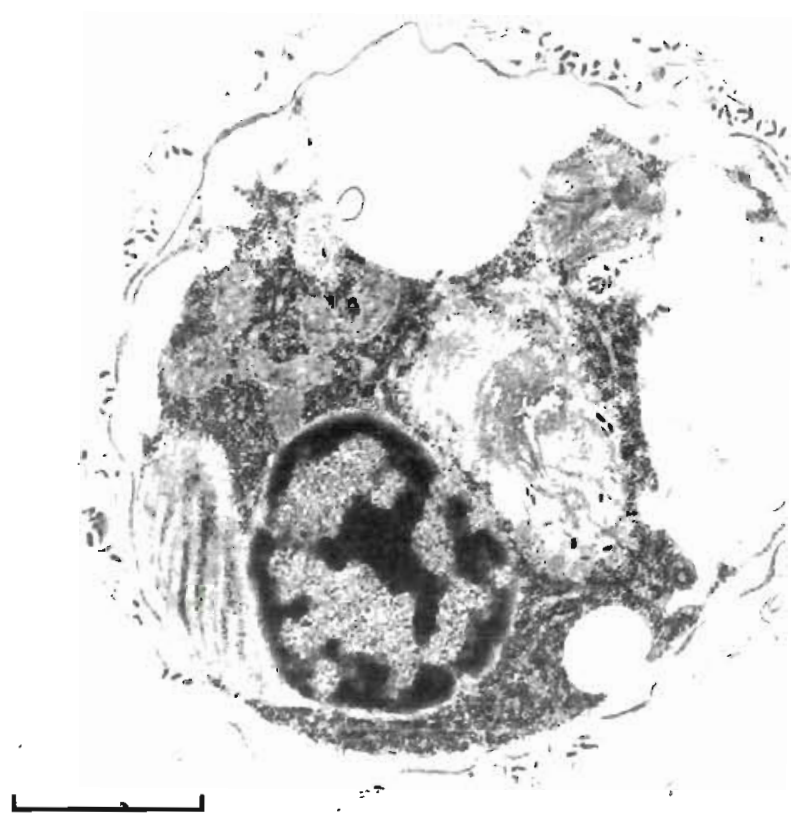

Fig. 3. Transmission electron micrographs of (A) a coccolithproducing cell of Emiliania huxleyi (C-cell) and (B) what could possibly be an organuc scales-bearıng cell of E. huxleyi (S-cell; J. C. Green pers comm.1. The densely stained material around the cell has been described for E. huxleyi S-cells by Van der Wal (1985). Note in the micrograph of the E huxleyi C-cell the intracellular outline (coccoliths have been lost during the preparative procedure) of the coccolith (C). Scale bar $=1 \mu \mathrm{m}$
Total numbers of E. huxleyi cells at the other stations were lower, with maximum values of $0.6 \times 10^{5} \mathrm{1}^{-1}$. Within the high reflectance area $E$. huxleyi made up 20 to $45 \%$ of total phytoplankton biomass as chl a in the mixed layer and only $<5 \%$ outside the high reflectance area. Using transmission electron microscopy (TEM), we found in addition to the coccolith producing cells (C-cells) significant numbers of what could possibly be organic scale-bearing cells (S-cells, Klaveness 1972, Van der Wal 1985, J. C. Green pers. comm.). It is difficult to identify the cells with certainty from TEM micrographs (Fig. 3), but the size of the cells and the form and diameter of the scales (in general $0.3 \mu \mathrm{m}$, and occasionally up to $0.5 \mu \mathrm{m}$ ) were comparable to the Scells described by Klaveness (1972). The occurrence of these cells only within the centre of the bloom and the fact that only they contained exactly the same type of VPLs as the C-cells furthermore suggest that we found S-celis of E. huxleyi in our natural samples. If so, the actual biomass of $E$. huxleyi was higher than mentioned above because with the method used to count E. huxleyi cells (Van der Wal et al. 1995) only coccospheres can be detected.

Bacterial production correlated significantly to chl a ( $\mathrm{p}<0.05, \mathrm{n}=39$ ). Bacterial production (Fig. 4 i main stations) within the mixed layer ranged between 0.1 and $2 \mu \mathrm{g} \mathrm{C}^{-1} \mathrm{~d}^{-1}$, with highest values at the stations inside the high reflectance area. Maximum rates

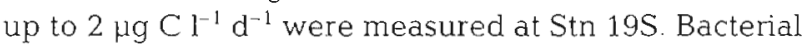
growth rates varied between 0.02 and $0.32 \mathrm{~d}^{-1}$, with highest rates estimated again at $\mathrm{Stn} 19 \mathrm{~S}$ (data not shown).

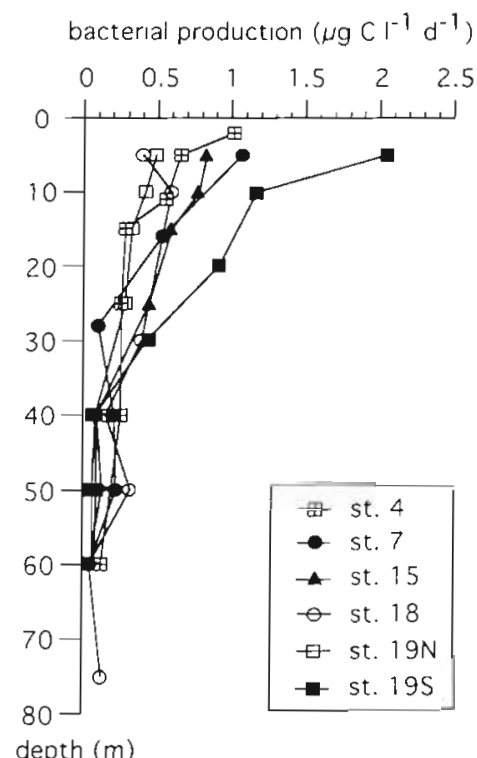

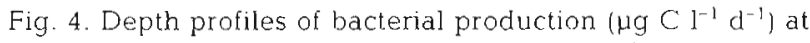
the main stations during a cruse in the North Sea dunng summer 1993 


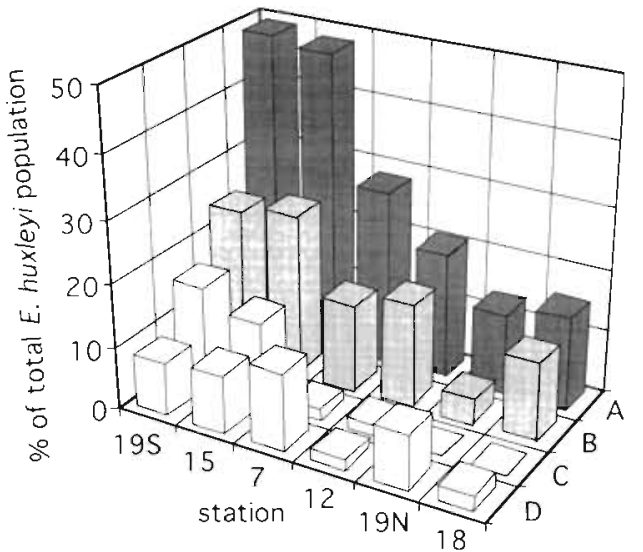

Fig. 5. Distribution of VLP-infected Emiliania huxleyi cells in June/July 1993 near the Shetland Islands (North Sea) as percentage of the total E. huxleyi population. A: Fraction of $E$. huxleyi cells visibly infected with VLPs; B: fraction of $E$. huxJeyi cells containing only small VLPs; C: fraction of E. huxleyl cells containing both VLP size classes within the same cell;

$D$ : fraction of E. huxleyi cells containing only large VLPS

\section{Virus-like particles}

Cells of Emiliania huxleyi infected with VLPs were observed at all stations checked, although the level of infection differed marked]y (Fig. 5) Highest percentages of $E$. huxleyi cells visibly infected were recorded within the high reflectance area, with maximum values of almost $50 \%$ at Stns 15 and 19S. An interesting feature was the detection of 2 types of VLPs in E. huxleyi (Fig. 6). Both types were hexagonal, suggesting icosahedral symmetry in 3-dimensional morphology (Caspar \& Klug 1962), but the size was different. The largest VLP was 185 to $200 \mathrm{~nm}$ in diameter, and the smallest VLP was at least 3 times smaller ( 50 to $60 \mathrm{~nm}$ ). Regularly, both size classes were present in the same cell. The small VLPs caused the higher degree of infection in E. huxleyi. The fraction of E. huxleyi cells containing both types of VLPs within the same cell was highest at Stns 15 and 19S. From Fig. 5 it becomes clear that the total level of infection caused by large VLPs (from cells with only large VLPs and with both types of VLPS) was never higher than $25 \%$. Lowest levels $(<10 \%)$ were recorded outside the high reflectance area. The average number of VLPs (both for large and small VLPS) per E. huxleyi cell section was always $<10$, with highest numbers within the high reflectance area. Maximum numbers of large VLPS $( \pm 25)$ and small VLPs $( \pm 30)$ per cell section were also found within this area. Stages of complete disruption of the organelles and lysis of the cells were frequently observed. Free large VLPs, counted for transect Stns 20 to 32 , ranged between 1.5 and $6 \times 10^{7} \mathrm{l}^{-1}, 2$ orders of magnitude higher than the cell number of $E$. huxleyi at these stations
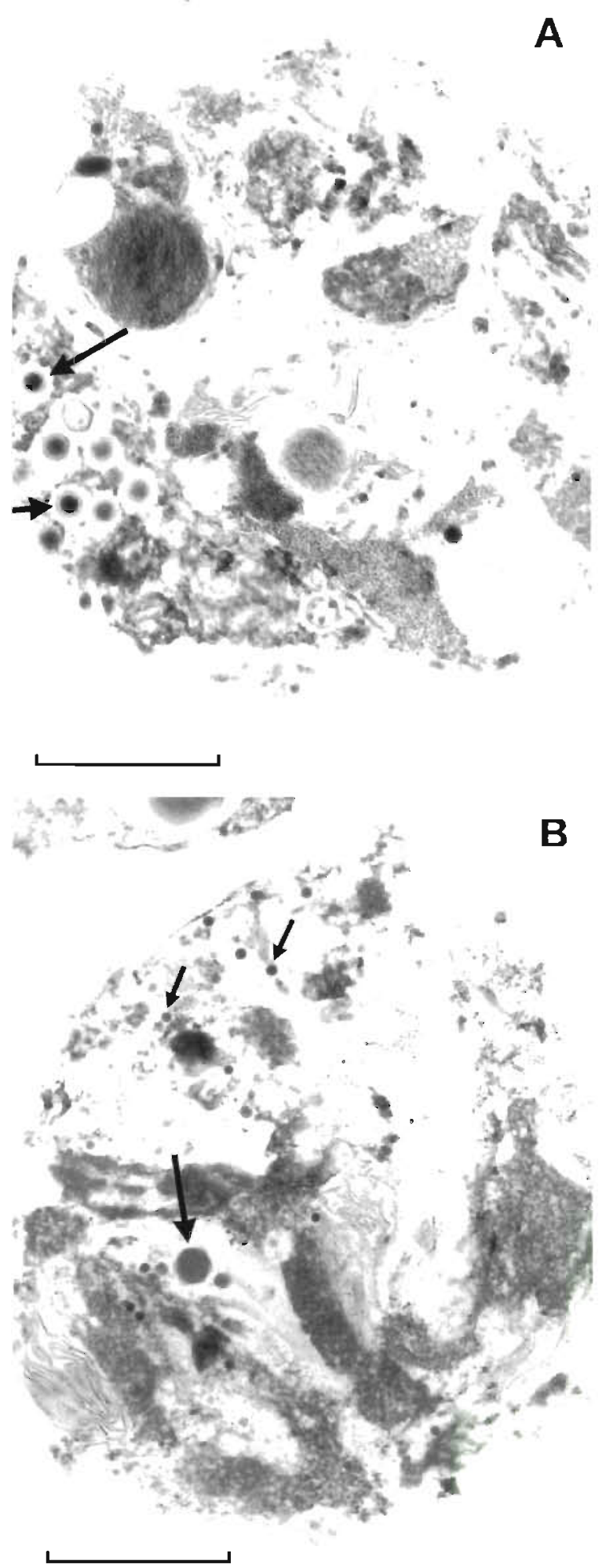

Fig. 6. Emiliania huxleyi. Electron micrographs of ultrathin sections showing E. huxleyi containing VLPs. (A) Infected cell with large VLPs (large arrows), and (B) infected cell with both VLP size classes (small VLPs indicated with small arrows). Note the moribund appearance of the cells. Scale bar $=1 \mu \mathrm{m}$ 

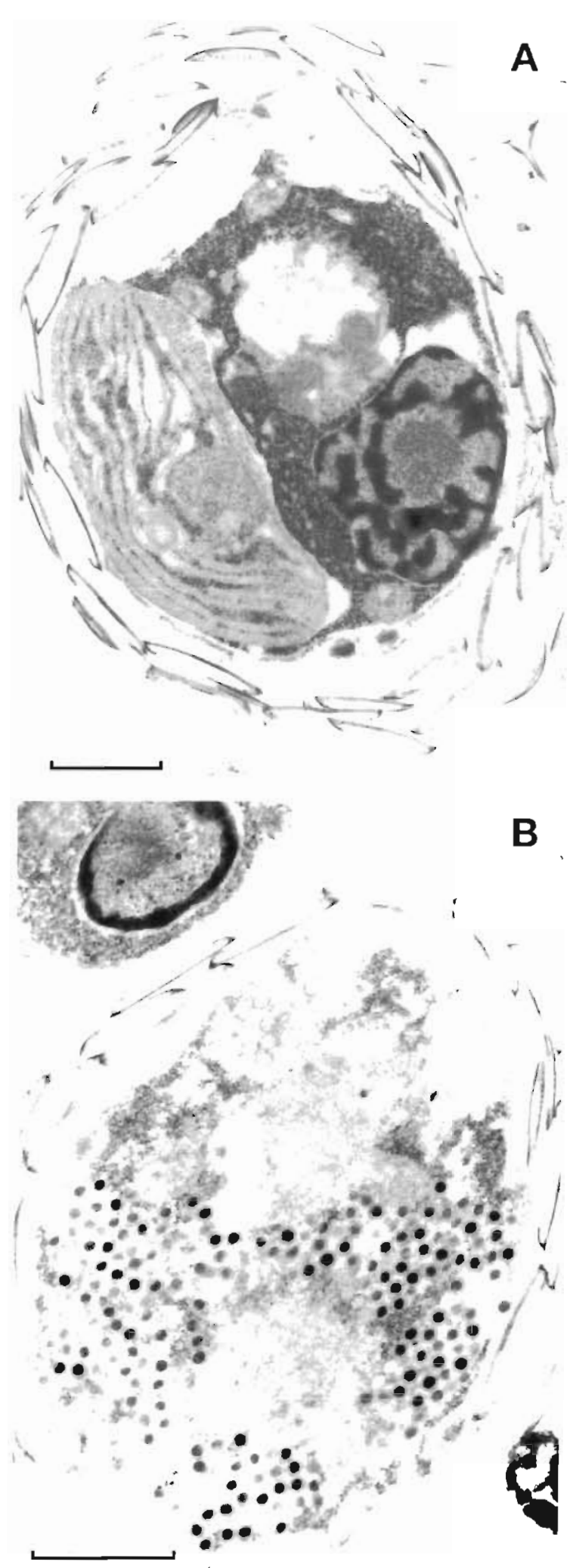

Fig. 7. Chrysochromulina sp. Electron micrograph of a Chrysochromulina sp. cell (A) without and (B) with intracellular VLPs. Note the high number of VLPs in a single thin section of an infected cell. Scale bar $=1 \mu \mathrm{m}$ $\left(0.05\right.$ to $\left.0.6 \times 10^{6} 1^{-1}\right)$. However, free large VLPs are produced not only by $E$. huxleyi, as other organisms are also known to have VLPs in this size class (Dodds 1979 , Van Etten et al. 1991, Reisser 1993, this study).

Apart from Emiliania huxleyi, we also found viral infection in a species of the genus Chrysochromulina (Fig. $7 ;$ J. C. Green pers. comm.). Although Chrysochromulina sp. was recorded at Stns 12, 15, 18, and 19S, infected cells were found only at Stns 15 and 195 . The VLPs were 100 to $110 \mathrm{~nm}$ in diameter and the average number was 170 VLPs per cell section. Only recently, Suttle \& Chan (1995) isolated viruses which lysed Chrysochromulina brevifilum and C. strobilus. The high number of VLPs in a single thin section in both studies is remarkable. No viral infections in other algae were observed in the thin sections. However, we did find large VLPs in several heterotrophic organisms.

\section{DISCUSSION}

\section{The bloom}

The high reflectance area (Fig. 1) corresponded to the input of run-off water, which facilitated stratification suitable for the development of Emiliania huxleyi blooms (Balch et al. 1991). Both chl a concentration $\left(0.7\right.$ sto $\left.1.5 \mu \mathrm{g} \mathrm{l}^{-1}\right)$ and $E$. huxleyi cell numbers in the bloom (max. $1.8 \times 10^{6} \mathrm{ml}^{-1}$ ) are comparable to values reported for $E$. huxleyi blooms under natural conditions by Balch et al. (1991) and Malin et al. (1993). The low ratio of living to dead E. huxleyi, combined with a high number of detached coccoliths (Van der Wal et al. 1995), indicate that the bloom was already at an advanced stage. Within the high reflectance area (decaying phase of the E. huxleyi bloom), nitrogen concentrations were low. According to Eppley et al. (1969), E. huxleyi becomes growth-limited on either nitrate or ammonium at concentrations below $1 \mu \mathrm{M}$. Riegman et al. (1992) and Egge \& Heimdal (1994) found E. huxleyi a poor competitor on nitrogen. Nitrogen limitation seem to have limited the growth of $E$. huxleyi within the high reflectance area, which is confirmed by $W$. Stolte (pers, comm.), who found phytoplankton within the decaying region to be nitrogen limited based on the ratio of intracellular glutamine to glutamate (an index for nitrogen limitation; Flynn 1990). No nitrogen limitation could be determined outside the bloom area.

\section{Viral interactions}

The highest level of visible viral infection in Emiliania huxleyi was found in the decaying phase of the 
bloom (inside the high reflectance area). The higher infection level at Stn 15 as compared to Stn 7 corresponds well with the lower ratio of living to dead $E$. huxleyi coccospheres found at this station by Van der Wal et al. (1995). Up to $50 \%$ of E. huxleyi had mature VLPs (both types) in the cell, which is quite high compared to most reports on viral infection of phytoplankton (Dodds 1979, Proctor \& Fuhrman 1990, Bratbak et al. 1993, Reisser 1993). High levels of viral infection within algal cells are reported for the green alga Platymonas sp. (30\%; Pearson \& Norris 1974), the scalebearing freshwater alga Paraphysomonas $175 \%$; Preisig \& Hibberd 1984) and the red tide alga Heterosigma akashiwo (11.5\%; Nagasaki et al. 1994). However, these results were obtained either from cultured algae or from natural samples only after incubation in the laboratory. As far as we are aware, this is the first study reporting on high levels of visible viral infection of phytoplankton under natural conditions. The North Atlantic station (Stn 18, which is located far outside the area of the E. huxleyi bloom) was sampled for reference. Surprisingly, we did not find a low level of visible viral infection in the low numbers of $E$. huxleyi present. A possible reason for this could lie in the paradoxal situation of high nutrient and low chl a concentrations, indicative of possible iron-limited growth (K. Timmermans pers. comm.)

The occurrence of 2 types of VLPs within the same cell has also been observed in Pyramimonas orientalis (Moestrup \& Thomsen 1974), Cryptomonas sp. (Pienaar 1976), and Chromophysomonas cornuta (Preisig \& Hibberd 1984). For Emiliania huxleyi only the occurrence of large VLPs has previously been recorded (Bratbak et al. 1993). The percentage of E. huxleyi cells in thin sections visibly infected with the large type of VLPs was between 15 and $25 \%$ in the decaying phase of the bloom, which again is high compared to the $3 \%$ during the collapse of an E. huxleyi bloom in mesocosms reported by Bratbak et al. (1993). These authors stated that their results may have been seriously underestimates, because cells containing large VLPS lysed during centrifugation and cells with only a few large VLPs may have escaped their attention. Although the first possible source of error also applies to our data, the frequently found moribund cells suggest no great loss of the delicate cells. Our thorough screening of the thin sections would seem to rule out the latter source of error.

A high percentage of cells containing intracellular VLP can be the result of a high viral infection rate or of synchronized induction of temperate viruses carried by a lysogenic host population. A bloom situation with a high host density will increase viral proliferation. However, it has been suggested that most viruses are temperate rather than virulent (Freifelder 1987, Bratbak et al. 1990), so the viral production rate will then depend on the induction rate in lysogenic host cells. In our study, the highest levels of viral infection were recorded in the nitrogen-limited decaying phase of the Emiliania huxleyi bloom. Enhanced viral production under low nitrogen concentrations has already been reported for E. huxleyi blooming in mesocosms (Bratbak et al. 1993). Since high levels of visible viral infection will lead to high lysis rates of the host cells, we conclude that viral lysis was an important factor in controlling the bloom of E. huxleyi in the North Sea during summer 1993.

\section{Viral lysis}

The 50 to $70 \mathrm{~nm}$ thin sections contain about $2.5 \%$ of the cell content of an Emiliania huxleyi cell. Using average numbers of 4 large VLPs (with a diameter of 185 to $200 \mathrm{~nm}$ ) and 9 small VLPs (50 to $60 \mathrm{~nm}$ diameter) per cell section, a total burst size of roughly 400 VLPs per cell was estimated for $E$. huxleyi in the decaying phase of the bloom. Comparable values were reported for E. huxleyi (Bratbak et al. 1993) and Synechococcus spp. (Suttle \& Chan 1993). Combined with the high level of viral infection, it is clear that viruses were an important source of mortality for E. huxleyi (Proctor \& Fuhrman 1990). In order to estimate the amount of released algal cellular carbon due to viral lysis, we assumed that all visibly infected $E$. huxleyi cells lysed within $24 \mathrm{~h}$. This assumption is based on the frequent occurrence of moribund, infected E. huxleyi cells and free VLPs in the ultrathin sections of stations within the decaying phase of the bloom, suggesting that E. huxleyi was already at a late stage of the latent period (Proctor et al. 1993). Viral lysis of E. huxleyi was highest within the high reflectance area, with rates of 2 to $4 \mu \mathrm{g}$ cellular $\mathrm{C}^{-1} \mathrm{~d}^{-1}$. In the borderline zone and outside the high reflectance area rates were always $<0.5 \mu \mathrm{g} \mathrm{C} \mathrm{^{-1 } \mathrm { d } ^ { - 1 }}$

The clear relationship found between bacterial production and phytoplankton abundance indicates that phytoplankton (by excretion and/or lysis) was the dominant source of organic matter for bacteria. Assuming a bacterial growth conversion efficiency of 0.3 (an intermediate value obtained on phytoplankton lysis products and detritus by Newell et al. 1981, Biddanda 1988 and Van Wambeke 1994), we estimated the bacterial carbon demands at VLP sampling depths (15 to $25 \mathrm{~m}$ ) to be 1 to $3 \mu \mathrm{g} \mathrm{C}^{-1} \mathrm{~d}^{-1}$. Our data suggest that viral lysis of Emiliania huxleyi within the decaying part of the bloom may have been an important source of organic carbon for bacteria. The nutrient-rich organic components released after cell lysis are very likely utilized quickly by bacteria. For a better 
understanding of the role of viral lysis of phytoplankton in the microbial food web we need more research on the level of viral infection within algae varying with depth.

\section{CONCLUSIONS}

From our data we conclude that viruses can be important agents for Emiliania huxleyi bloom decay under natural conditions. The severe viral infection of Chrysochromulina sp. reported in this study is another example of the regulating effect of viruses on population dynamics. Our results furthermore suggest that viral lysis of E. huxleyi can significantly influence the microbial food web under natural blooming conditions by introducing nutrient-rich organic components into the system. This study seems to confirm the results of the modified model of Fuhrman \& Suttle (1993), in which the authors included not only the viral infection of bacteria, but also of phytoplankton. With a phytoplankton mortality rate due to viruses of only $10 \%$, they observed an increased bacterial production which was $33 \%$ above the level without viruses. Although our study clearly shows that viral infection should be included in models concerning carbon cycling, we want to stress that more knowledge on whether viruses are lytic or lysogenic is needed. And, if the viruses are lysogenic, the factors which induce viral lysis of $E$. huxleyi and phytoplankton in general need to be known. Also, the occurrence of what possibly were S-cells of $E$. huxleyi raises the question of whether or not the different stages are equally vulnerable to viral infection or induction. Further study is needed of hypotheses such as: (1) S-cells are more easily infected by viruses than $C$-cells, because they have no coccoliths to protect them; or (2) the transition from C-cell to S-cell, seen during senescence (Klaveness 1972), induces virus proliferation.

With the inclusion of viruses in models, we should keep in mind that, although small VLPs are generally classified as bacteriophages (Cochlan et al. 1993), small VLPs are also regularly recorded in phytoplankton (Van Etten et al. 1991, this study). If a significant fraction of viruses or VLPS from eukaryotes are in the size range of $<70 \mathrm{~nm}$, the viral mortality of the bacterial fraction has often been overestimated. This may, for example, partly explain the lack of balance in the C-budget of Bratbak et al. (1992)

Acknowledgements. We are indebted to Gert-Jan Gast for excellent shipboard support and to Frans Prins (Laboratory for Pathology, Academic Hospital Lejden) for his consent to use the transmission electron microscope and for his friendly and sound advice. We are grateful to Prof. J. C. Green for identification of Chrysochromulina sp. and for his comments on what might be Emiliania huxleyi S-cells. We thank Paul van der Wal for additional unpublished data on E. huxleyt coccosphere abundance, Karel Bakker for nutrient analyses and the crew of the RV 'Pelagia' for their practical support during the cruise. We thank Gunnar Bratbak for his moral support at the start of this study and, together with 2 anonymous reviewers, for critically reading the manuscript. NIOZ publication no. 3016 .

\section{LITERATURE CITED}

Balch WM, Holligan PM, Ackleson SG, Voss KJ (1991) Biological and optical properties of mesoscale coccolithophore blooms in the Gulf of Maine. Limnol Oceanogr $36(4): 629-643$

Biddanda BA (1988) Microbial aggregation and degradation of phytoplankton-derived detritus in seawater. II. Microbral metabolism. Mar Ecol Prog Ser 42:89--95

Bratbak G, Egge JK, Heldal M (1993) Viral mortality of the marine alga Emiliania huxleyi (Haptophyceae) and termination of algal blooms. Mar Ecol Prog Ser 93:39-48

Bratbak G, Heldal M, Norland S, Thingstad TF (1990) Viruses as partners in spring bloom microbial throphodynamics. Appl Environ Microbiol 56(5):1400-1405

Bratbak G, Heldal M, Thingstad TF, Riemann B, Haslund $\mathrm{OH}$ (1992) Incorporation of viruses into the budget of microbial C-transfer. A first approach. Mar Ecol Prog Ser 83: $273-280$

Bratbak G, Thingstad F, Heldal M (1994) Viruses and the microbial loop. Microb Ecol 28:209-221

Caspar DLD, Klug A (1962) Physical principles in the construction of regular viruses. Cold Spring Harbor Symp Quant Biol 27:1-24

Cochlan WP, Wikner J, Steward GF, Smith DC, Azam F (1993) Spatial distribution of viruses, bacteria and chlorophyll a in neritic, oceanic and estuarine environments. Mar Ecol Prog Ser 92:77-87

Conte $\mathrm{MH}$, Thompson A, Eglinton G (1995) Lipid biomarker diversity in the coccolithophorid Emiliania huxleys (Prymnesiophyceae) and the related species Gephyrocapsa oceanica. J Phycol 31:272-282

Cottrell MT, Suttle CA (1991) Wide-spread occurrence and clonal variation in viruses which cause lysis of a cosmopolitan, eukaryotic marine phytoplankter, Micromonas pusilla. Mar Ecol Prog Ser 78:1-9

Dodds JA (1979) Viruses of marine algae. Experientia $35(4): 440-442$

Egge JK. Heimdal BR (1994) Blooms of phytoplankton including Emiliansa huxleyi (Haptophyta). Effects on nutrient supply in different N:P ratios. Sarsia 79:333-348

Eppley RW, Rogers JN, McCarthy JJ \{1969) Half-saturation constants for uptake of nitrate and ammonium by marne phytoplankton. Limnol Oceanogr 14:912-920

Flynn K (1990) The determination of nitrogen status in microalgae. Mar Ecol Prog Ser 61:297-307

Freifelder D (1987) Molecular biology. Jones \& Bartlett Publishers, Inc, Boston

Fuhrman J (1992) Bacterioplankton roles in cycling of organic matter: the microbial food web. In: Falkowski PG. Woodhead AD (eds) Primary productuvity and biogeochemical cycles in the sea. Plenum Press, New York, p 361-383

Fuhrman JA, Suttle CA (1993) Viruses in marine planktonic systems. Oceanography 6(2):51-63

Holm-Hansen O, Lorenzen CJ, Holmes RW, Strickland JDH (1965) Fluorometric determination of chlorophyll. J Cons Perm Int Explor Mer 30(1):3-15 
Klaveness D (1972) Coccolithus huxleyi (Lohm.) Kamptn. II. The flagellate cell, aberrant cell types, vegetative propagation and life cycles. Br Phycol J 7:309-318

Kristiansen S (1987) Nitrate reductase activity in phytoplankton from the Oslo-fjord, Norway. J Plankton Res 9(4): $739-748$

Lee A (1970) The currents and water masses of the North Sea. Oceanogr Mar Biol A Rev 8:33-71

Malin G, Turner S, Liss P, Holligan P, Harbour D (1993) Dimethylsulphide and dimethylsulphoniopropionate in the Northeast Atlantic during the summer coccolithophore bloom. Deep Sea Res I 40(7):1487-1508

Mayer JA (1977) A viral infection in the marine Prasinophycean alga, Micromonas pusilla. J Phycol 13 (Suppl): 44

Moestrup $\oslash$. Thomsen HA (1974) An ultrastructura] study of the flagellate Pyramimonas orientalis with particular emphasıs on Golgi apparatus activity and the flagellar apparatus. Protoplasma 81:247-269

Nagasaki K, Ando M, Itakura S, Imai I, Ishida Y (1994) Vira] mortality in the final stage of Heterosigma akashiwo (Rhaphidophyceae) red tide. J Plankton Res 16(11):1595-1599

Newell RC. Lucas MJ, Linley EAS (1981) Rate of degredation and efficiency of conversion of phytoplankton debris by marine microorganisms. Mar Ecol Prog Ser 6:123-136

Paasche E, Klaveness D (1970) A physiological comparison of coccolith-forming and naked cells of Coccolithus huxleyi. Arch Mikrobiol 73:143-152

Pearson BR, Norris RE (1974) Intranuclear virus-like particles in the marine alga Platymonas sp. (Chlorophyta, Prasinophyceae). Phycologia 13(1):5-9

Pienaar RN (1976) Virus-like particles in three species of phytoplankton from San Juan Island, Washington. Phycologia 15(2): 185-190

Preisig HR, Hibberd DJ (1984) Virus-like particles and endophytic bacteria in Paraphysomonas and Chromophysomonas (Chrysophyceae). Nord J Bot 4(2):279-285

Proctor LM, Fuhrman JA (1990) Viral mortality of marine bacteria and cyanobacteria. Nature 343:60-62

Proctor LM, Okubo A, Fuhrman JA (1993) Calibratung estimates of phage-induced mortaluty in marine bacteria ultrastructural studies of marine bacteriophage develop-

Responsible Subject Editor: G. Bratbak, Bergen, Norway ment from one-step growth experiments. Microb Ecol 25: $161-182$

Reisser W (1993) Viruses and virus-like particles of freshwater and marine eukaryotic algae-a review. Arch Protistenkd $143: 257-265$

Riegman R, Noordeloos AAM, Cadée GC (1992) Phaeocystis blooms and eutrophication of the continental coastal zones of the North Sea. Mar Biol 112:479-484

Sieburth JMCN, Johnson PW, Hargraves PE (1988) Ultrastructure and ecology of Aureococcus anophagefferens gen. et sp. nov. (Chrysophyceae): the dominant phytoplankter during a bloom in Narragansett Bay, Rhode Island, summer 1985. J Phycol 24:416-425

Simon M, Azam F (1989) Protein content and protein synthesis rates of planktonic marine bacteria. Mar Ecol Prog Ser 51:201-213

Suttle CA, Chan AM (1993) Marine cyanophages infecting oceanic and coastal strains of Synechococcus: abundance, morphology, cross-infectivity and growth characteristics. Mar Ecol Prog Ser 92:99-109

Suttle CA, Chan AM (1995) Viruses infecting the marine Prymnesiophyte Chrysochromulina spp.: isolation, preliminary characterization and natural abundance. Mar Ecol Prog Ser 118:275-282

Suttle CA, Chan AM, Cottrell MT (1991) Use of ultrafiltration to isolate viruses from seawater which are pathogens of marine phytoplankton. Appl Environ Microbiol 57(3): $721-726$

Van der Wal P (1985) Cytochemical and X-ray microanalysis studies of intracellular calcium pools in scale-bearing cells of the coccolithophorid Emiliania huxleyi. Protoplasma $124: 1-9$

Van der Wal P, Kempers RS, Veldhuis MJW (1995) Production and downward flux of organic matter and calcite in a North Sea bloom of the coccolithophore Emıliania huxleyi. Mar Ecol Prog Ser 126:247-265

Van Etten IL Lane, LC Meints RH (1991) Viruses and viruslike particles of eukaryotic algae. Microb Rev 55(4): $586-620$

Van Wambeke F (1994) Influence of phytoplankton lysis or grazing on bacterial metabolism and trophic relationships. Microb Ecol 27:143-158

Manuscript first received: October 13, 1995

Revised version accepted: January 12, 1996 